\title{
5. Water Planning and Native Title: A Karajarri and Government Engagement in the West Kimberley ${ }^{1}$
}

\author{
Jessica K Weir, Roy Stone and Mervyn Mulardy Jnr
}

\begin{abstract}
We're a coastal tribe, but we live in a desert area. We depend almost exclusively on the rain that comes down and the water that's holding the groundwater table. ... If our soaks and springs start to dry up, then the trees will start to die off and the animals will start to die too. Because we do live in the edge of the desert and in the desert area, the water is so important for us for our living area. We'll continue to negotiate with all the other stakeholders in our country, and do the work that's required, so we get the proper benefits out of all of that. (J Edgar, Deputy-Chair Karajarri Traditional Lands Association, comment from the floor, National Native Title Conference 2008, Perth, 5 June 2008)
\end{abstract}

With prolonged drought and climate change, water has once again come into focus in national, state and territory policy development, prompting the review of water planning and management. As part of this, policy makers have revisited the complexities of establishing large-scale industrial agriculture in Australia's tropical monsoon country (Ross, 2009). Water planning in Karajarri country in the West Kimberley of Western Australia is occurring within this context. For Karajarri, they hope that the planning process will help ensure that water is treated the 'right way' for country (Mulardy Jnr cited in Mathews, 2008).

Karajarri have an important water story to tell. Their life in and on the fringes of the Great Sandy Desert has always depended on the flowing fresh groundwater that is also called the La Grange Basin (Figure 5.1). Karajarri describe this water as 'living water', and relate powerful stories to how the water moves through country (Yu, 1999). In the late 1990s a large scale cotton irrigation proposal threatened to upset these relationships. At the same time, Karajarri were in the process of having their native title rights recognised (Figure 5.2). The irrigation proposal lead to a range of government funded studies into the stakeholder, cultural and ecological values that are supported by La Grange groundwater. The majority of stakeholders held concerns over the impact of such a large

\footnotetext{
1 This paper has developed out of a presentation given by Roy Stone at the National Native Title Conference 2008, Perth, 5 June 2008. The authors thank Joe Edgar, Anna Mardling, Luke Taylor, Tran Tran and two anonymous peer reviewers for their comments on an earlier draft. Our thanks also go to Sarah Yu for her assistance with place names.
} 
irrigation proposal for this small community and arid country. These studies revealed intimate, complex and life-sustaining relationships that thrive on the freshwater, which could be jeopardised by the large-scale extraction of groundwater. Fortunately for the people holding these concerns, the irrigation proposal did not go ahead.

This paper describes the successful local opposition to the cotton proposal, however, this paper is not set around this event. Rather, the event is a meaningful prompt for discussions about how water decisions are being made, how they could be made, and how water planning could be better designed to support development aspirations of the communities within the Basin. In the preparation of a water allocation plan for the La Grange groundwater area. Karajarri and the Western Australian Department of Water have sought to find a common ground through engagement, dialogue and research into water management and understandings of water. This plan has now been finalised as the La Grange groundwater allocation plan (Department of Water, 2010).

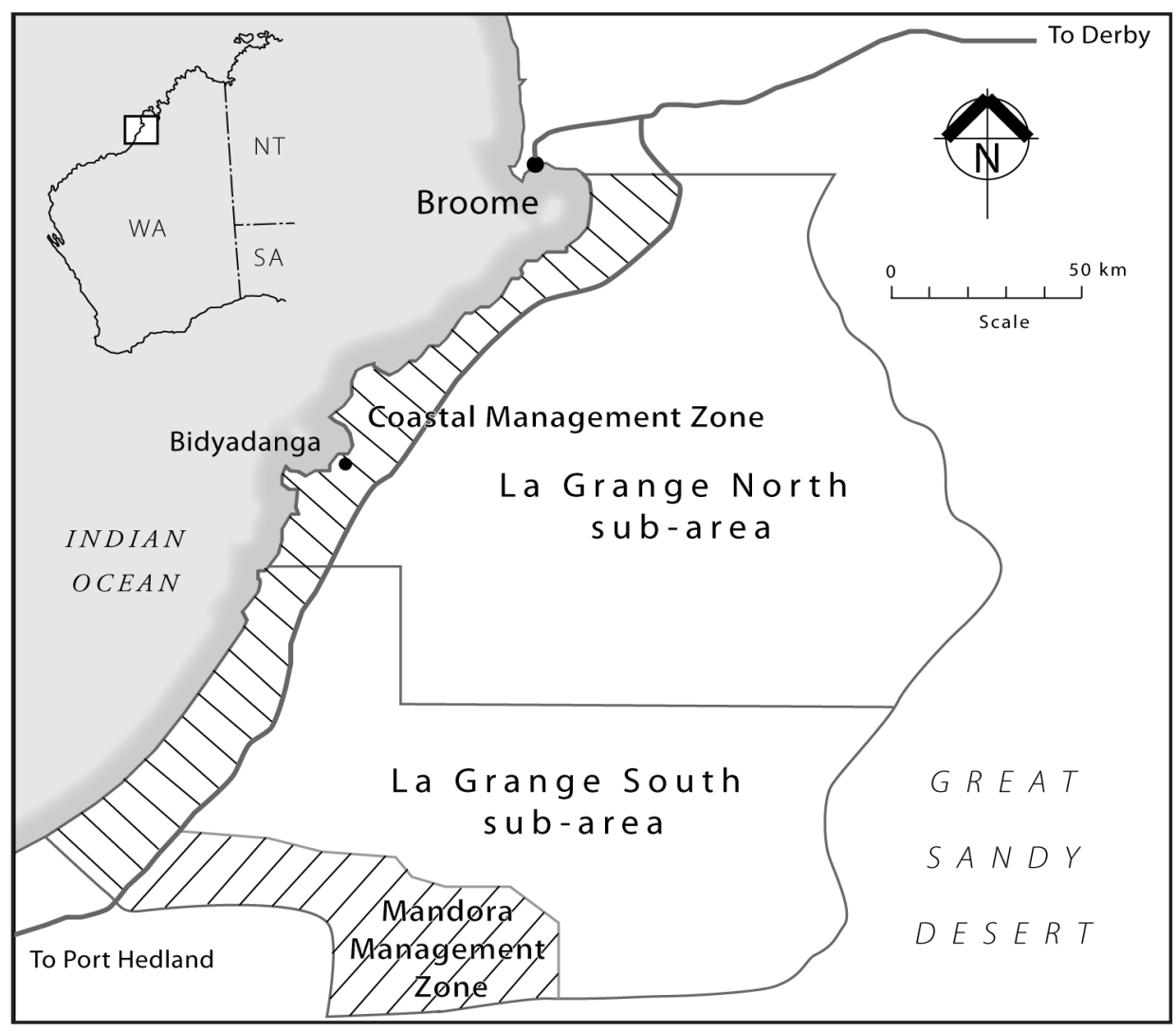

Figure 5.1: Potential management zones for the La Grange sub-basin.

Source: Adapted from Roy Stone, PowerPoint presentation, National Native Title Conference, Perth, 5 June 2008. 


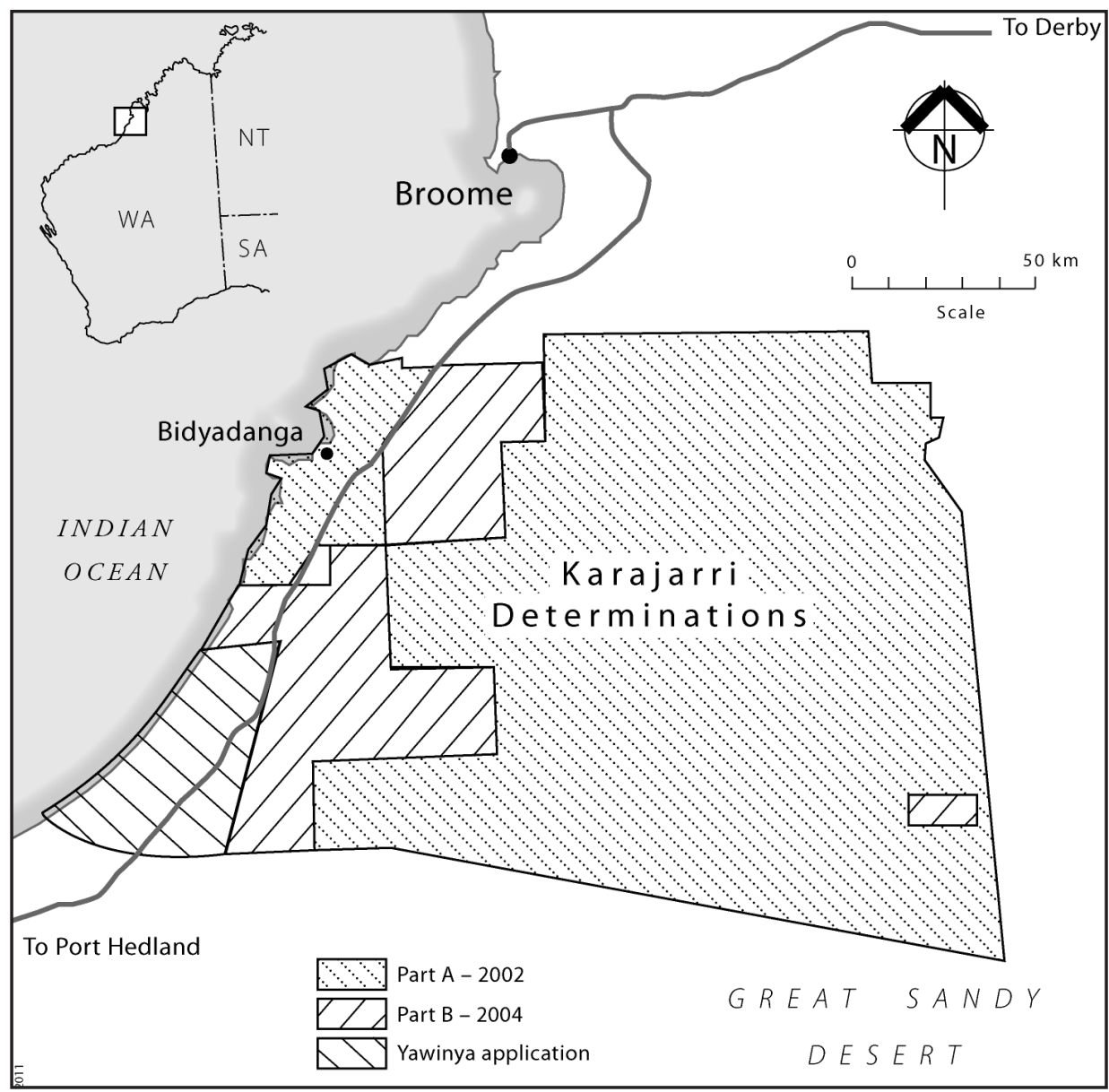

Figure 5.2: Karajarri 2002 and 2004 native title consent determinations, and the Yawinya native title application which is in negotiation with Nyangumarta. Part $A$ is chiefly exclusive native title rights, and Part $B$ is chiefly nonexclusive native title rights. Part B includes the inland Dragon Tree Soak Nature Reserve, which was determined as extinguishing native title.

Source: Adapted from National Native Title Tribunal, 2004, and National Native Title Tribunal, 2011.

\section{Cotton and native title}

The La Grange Basin is one of Western Australia's (WA) largest groundwater resources. This is the arid country of the Great Sandy Desert, including where the desert meets with the Indian Ocean along the West Australian coastline south of Broome. Prior to this planning process, little water in the La Grange Basin was allocated for consumptive use by humans, with licensed use of water at 1.8 gigalitres per year and unlicensed (stock, domestic purposes, drinking 
water) at 3.0 gigalitres (Department of Water, 2008: 17). These uses include the domestic water supply for the community of Bidyadanga and some small scale horticulture. Water is also profoundly important to Karajarri for many other reasons in addition to human consumption. The health of country, including many wetlands, plants and animals, are all dependent on the fresh groundwater.

In the 1990s, the private company Western Agricultural Industries (WAI) became interested in the potential of this freshwater to support irrigation industry. Whilst a range of crops of interest were identified (such as sugar cane, leucaena, exotic hardwoods, hemp, viticulture, freshwater aquaculture), cotton production was the main focus. In the late 1990s the WA government called for expressions of interest in the development of large scale irrigated agriculture in the west Kimberley. In response WAI developed the West Kimberley Irrigation Proposal, a two stage development. The first stage relied on an allocation of more than 90 per cent of the La Grange groundwater potentially available for consumptive use to support an envisaged 20,000 hectares of irrigated cotton fields. The second stage would expand this industry by diverting water from the Fitzroy River, which is far to the east of Karajarri country. Fitzroy water would be diverted west and then south by an irrigation canal to support a much larger 200,000 hectares of cotton production. This extraction and diversion of water was designed to take advantage of the free draining soils of the Karajarri coast, which is Pindan country with acacia thickets and low trees. This coastal strip is also where pastoralists have leased land for pastoral stations.

In 1998, WAI signed a Memorandum of Understanding with the WA government to carry out a feasibility investigation of the WAI proposal. Whilst not a legal contract, the Memorandum of Understanding indicated the WA government's intention to support the irrigation industry, dependent on the proposal's feasibility. Because of the size of the WAI proposal, it also triggered initiation of a sub-regional water allocation plan for the La Grange groundwater. The policy of the WA department responsible for water, the Water and Rivers Commission (known today as the Department of Water), held that where a single large development proposal generates the need for such an allocation plan, the development proponent must undertake and fund much of the groundwater investigation. This ensures the government does not meet the feasibility study costs of a private developer (Beckwith and Associates, 1999: 16). WAI was instructed to undertake a feasibility study into ground water use from the La Grange resource and a pre-feasibility study of surface water use from the Fitzroy River. A groundwater investigation licence was granted to WAI for exploration of the La Grange groundwater resource. In 1999, WAI began cotton trials at Shamrock Gardens pastoral station on the Karajarri coast (Beckwith and Associates, 1999: 3). 
Whilst the WAI proposal was being investigated, Karajarri were progressing work towards the formal recognition of their native title rights and interests. Their 1996 native title application was initially in response to a new pastoral fence on Shamrock station. The fence extended from a turkey nest dam that had been recently constructed by WAI. Karajarri elder Wittidong Mulardy was concerned because it interfered with Karajarri access to the culturally significant Parturr hills. In addition to their native title application, Karajarri investigated ways to purchase the pastoral leases for the two stations Shamrock and Nita Downs. However, the leases to Shamrock and Nita Downs were purchased by WAI as part of their cotton proposal. Karajarri decided to expand their native title to almost a 'whole of country' application to take a more comprehensive approach to such matters (Yu, 1998: 1; S Yu, pers comm, 7 May 2008). With additional applications made in 1997 and 1999, Karajarri lodged a combined native title application in 2000.

As the native title work progressed, the cotton proposal became intimately interlinked with it. WAI, as owner of the Shamrock and Nita Downs pastoral stations, would need to agree to any native title consent determination covering that area. But WAI in turn needed access to other lands on Crown radical title (unallocated Crown land) ${ }^{2}$ to carry out groundwater drilling investigations and this was constrained by the Karajarri native title application. In 2001, WAI decided to stop the La Grange groundwater investigation work until the native title issues were determined.

As part of their native title application, Karajarri prepared extensive evidence for the Federal Court with professional expertise coordinated and provided by the Kimberley Land Council. Their application was opposed in the Federal Court by the State of Western Australia, the Commonwealth government, the Shire of Broome, Telstra, pastoral and agricultural interests, pearling companies and fishing interests, exploration companies and the Bidyadanga Community Council. Federal Court Justice North found that the strength of the applicants' evidence and expert evidence was such that native title mediation would be better than litigation. That is, Karajarri native title should be determined by agreement between the parties.

In 2002 and 2004 two consent determinations were agreed upon by all parties and signed off by the Federal Court. The 2002 consent determination focused largely on Crown radical title, and recognised that Karajarri held exclusive native title rights and interests to 'possess, occupy, use and enjoy' their country 'to the exclusion of all others' (Nangkiriny $v$ Western Australia, 2002; see also,

2 Prior to the Mabo decision (Mabo v Queensland [No 2] (1992) 175 CLR 1), Crown radical title was called unallocated Crown land within the Australian property law system. Such lands continue to be commonly described as unallocated Crown land even though the High Court has determined otherwise. 
Weir, 2011 and Edgar, forthcoming). In 2004, the parties reached their second consent determination, the majority of which recognised non-exclusive native title rights and interests over the pastoral leases (Nangkiriny $v$ Western Australia, 2004). The outcomes of these two consent determinations are summarised in Table 5.1.

\section{Table 5.1: Karajarri native title rights and interests}

In the 2002 consent determination, Karajarri are recognised as holding exclusive native title rights and interests to 'possess, occupy, use and enjoy' their country 'to the exclusion of all others'. The Federal Court described this as including:

i. the right to live on the land;

ii. the right to make decisions about the use and enjoyment of the land and waters;

iii. the right to hunt, gather and fish on the land and waters in accordance with their traditional laws and customs for personal, domestic, social, cultural, religious, spiritual, ceremonial and communal needs;

iv. the right to take and use the waters and other resources accessed in accordance with their traditional laws and customs for personal, domestic, social, cultural, religious, spiritual, ceremonial and communal needs;

v. the right to maintain and protect important places and areas of significance to the Karajarri people under their traditional laws and customs on the land and waters;

and

vi. the right to control access to, and activities conducted by others on, the land and waters, including the right to give permission to others to enter and conduct activities on the land and waters on such conditions as the Karajarri people see fit.

Most of the 2004 consent determination concerned the pastoral stations Nita Downs Station, Shamrock Station, and part of Anna Plains Station, as well as the De Grey Stock Route and a number of other small areas of land. Karajarri non-exclusive native title interests are recognised as existing in this area. These are: 
i. the right to enter and remain on the land and waters;

ii. the right to camp and erect temporary shelters;

iii. the right to take fauna and flora from the land and waters;

iv. the right to take other natural resources of the land such as ochre, stones, soils, wood and resin;

v. the right to take the waters including flowing and subterranean waters;

vi. the right to engage in ritual and ceremony;

and

vii. the right to care for, maintain and protect from physical harm, particular sites and areas of significance to the Karajarri people.

With respect to native title rights to water, the Native Title Act 1993 (Cth) makes explicit reference to the fact that native title rights and interests extend to both 'land and waters'. Waters are defined as including:

(a) sea, a river, a lake, a tidal inlet, a bay, an estuary, a harbour or subterranean waters; or

(b) the bed or subsoil under, or airspace over, any waters (including waters mentioned in paragraph (a)); or

(c) the shore, or subsoil under or airspace over the shore, between high water and low water. (Native Title Act 1993 (Cth): s 253) ${ }^{3}$

However, where water is a resource for consumptive use by humans, the Native Title Act 1993 (Cth) confirms any Commonwealth, State and Territory legislation that asserts ownership of natural resources, and/or the right to use, control and regulate water (Native Title Act 1993 (Cth): s 212). The High Court has argued that this vesting is sufficient to prevent exclusive native title possession of the water, with only the right to take remaining (Strelein and Weir, 2008; see also, for the High Court's findings, Western Australia $v$ Ward, 2002: para 263; and, for an apparent contrast to these findings, see the High Court decision in Yanner $v$ Eaton, 1999). That is, the native title holders only have usufructuary or use rights, not ownership rights, to the water. Thus, the legal framework for native title and water emphasises the continuation of the current water governance arrangements with limited opportunity for native title holders to

3 Land is defined as 'the airspace over, or subsoil under, land' and does not include 'waters', Native Title Act 1993 (Cth): s 253. 
make decisions about water allocations that could have a major impact on their rights and interests. Yet without water, Karajarri would not be able to enjoy or exercise the majority of their native title rights and interests.

In addition to this legal limitation, Karajarri native title rights and interests in water are further constrained by the details of their consent determinations. Every native title determination is different, reflecting the particular traditional laws and customs of the native title holders, and the types of land tenures and legislation in the determination area. Where native title is reached through consent, it is also usual for specific deals and compromises to be made as part of the mediation process. For Karajarri, most categories of fresh water have been excluded by the way water is defined in the 2002 consent determination:

'the waters' means the waters within Determination Area A excluding flowing and subterranean waters;

'flowing and subterranean waters' means those waters within Determination Area A which are:

(a) waters which flow, whether permanently, intermittently or occasionally, within:

(i) any river, creek, stream or brook; and

(ii) any natural collection of water into, through, or out of which a river, creek, stream or brook flows; and

(b) waters from and including an underground water source, including water that percolates from the ground;

The same exclusions about water were made in the 2004 consent determination.

Such constraints leave native title holders with limited direct say in water decisions, thereby raising the importance of water licencing and planning processes in Western Australia to protect their native title rights and interests. Water planning is designed to provide for the domestic needs of native title holders (and others) before water is allocated for irrigation or other major use. Likewise the planning process is designed to ensure that sufficient water is retained in the natural environment to support ecological and cultural values including native title rights such as law, language, religion, identity, and living on country, including hunting and fishing. This planning approach recognises the key role of water in supporting valued relationships with healthy country.

Nearby to Karajarri country to the north-west, the Camballin irrigation project in the 1960s and 1970s is an instructive local example of the negative effects of poor water management and regulation. Here, the diversion and storage of 
surface water sources was undertaken through the construction of a dam, a creek and a barrage on the Fitzroy River, and land was cleared and levelled to grow crops such as sorghum and cotton. However, the project's aims were thwarted by monsoonal weather, and insect pests. This country was transformed by river channel erosion, the poisoning of wildlife from chemicals, and, as the project was abandoned, the land turning into a dust bowl (Yu, 1999: 10-11). Aware of such concerns, as part of their proposal WAI made the argument that they would be working with new irrigation technologies, that were less dependent on the heavy chemicals as these earlier Camballin cotton trials and other cotton trials in the Ord region of the Kimberley and they would not be growing cotton on a flood plain subject to flooding and erosion but on free draining soils with controlled trickle irrigation. Yet there remained many outstanding issues for Karajarri. As Karajarri man Mervyn Mulardy Jnr describes:

They said they had a different technical style of irrigating cotton, but they wanted to use a lot of water. ... The cotton people were saying a lot of valuable water was being wasted out into the ocean. ... They [the Water and Rivers Commission] paid me to do consultant work between the traditional owners and them. The traditional owners were interested in other things that would not harm the environment, not cotton. Our old people said this water was not being wasted out into the ocean. (Mervyn Mulardy Jnr, interview, Bidyadanga, 14 October 2008)

Mervyn Mulardy Jnr, a co-author of this paper, was at the forefront of the campaign to stop the cotton, a campaign that extended to the Fitzroy River, and was also a leader for his community's battle for the recognition of their native title.

Karajarri had very limited native title fresh water rights, however, the WAI West Kimberley Irrigation Proposal did not go ahead. Karajarri were able to successfully oppose the cotton proponents with two key elements: native title rights to the land; and, the timing of administration processes in relation to the granting of water investigation licences.

In 1999, the Water and Rivers Commission had issued WAI with a groundwater investigation licence and required the company to go well inland from the coast to investigate and better understand the groundwater resource. To carry out this groundwater investigation work WAI needed land access to lands under Crown radical title which were also proposed for the recognition of Karajarri native title in the 2002 consent determination (described as area A). Hence before agreeing to this consent determination in 2002 WAI negotiated an Access Agreement with the Karajarri People which was included as Annexure A of the determination. The Access Agreement was specifically tied to the WAI's 
groundwater investigation licence from the Water and Rivers Commission. Unfortunately for WAI this licence expired in late 2004; they had neglected to renew it. Thus WAI's Access Agreement with the Karajarri became null and void.

To obtain a new groundwater investigation licence, WAI needed access to the land and permission from the land holder. However the 2002 Karajarri native title consent determination recognised Karajarri exclusive rights to area A, including 'the right to control access to, and activities conducted by others on the land'. Thus, in 2005 WAI were placed in the position of asking the opponents to the cotton proposal for land access for investigation work required before they could proceed with their cotton proposal. Because of this impasse, in 2005 the State Government allowed the Memorandum of Understanding between the State Government and WAI to expire without extension. The Water and Rivers Commission considered that WAI had not met their groundwater feasibility investigation obligations under the Memorandum of Understanding and were unlikely to do so and hence the Memorandum of Understanding should not be extended. WAI corporate leaders threatened to take legal action against the WA government for breach of contract, but they had no legal basis to do so.

\section{The issues: three studies}

Alongside this activity around cotton and native title, the Water and Rivers Commission began a water planning process to assess the proposal. The State government began with scoping the issues from talking with key stakeholders, and then setting out a work program for how these issues could be checked and investigated (Beckwith and Associates, 1999). Overall, three key studies were undertaken as part of the initial phase of the planning process: an overview of stakeholder issues by consulting company Beckwith and Associates (1999); a report on Aboriginal cultural values by anthropologist Sarah Yu (1999); and, a hydro-ecological survey of the wetlands of the north-western Great Sandy Desert by wetland scientists Vic and Christine Semeniuk (2000).

For the overview of stakeholder issues, Beckwith and Associates interviewed a diverse range of people, including Karajarri, Bidyadanga community people, public and private industry interests, relevant government departments, Indigenous and environmental organisations (such as the Kimberley Land Council and Environs Kimberley), and local government. Beckwith and Associates documented a range of general concerns made about the WAI proposal. Many stakeholders were concerned about the impacts of chemical pesticides and fertilisers that are used to grow cotton. People were most concerned about the possible contamination of the groundwater. Chemical exposure was also raised in relation to aerial spraying and the run-off of surface water after cyclonic events. 
Stakeholders were also worried about the environmental impact of taking so much groundwater, and how this would affect domestic supply, pastoral operations, environmental features, and the possibility of future land uses. Beckwith and Associates also revealed that not much was known about the local Pindan ecology, and that this may result in the Pindan being disregarded as desert land. Further, this lack of knowledge about the Pindan extended to other key ecological features, including groundwater wetlands and the many unknown subterranean aquatic animals that likely live in the groundwater (stygofauna). Many people were concerned about the reduction in groundwater levels occurring without explicit knowledge of the effects of this loss (Beckwith and Associates, 1999: 4-6).

Additionally, Beckwith and Associates identified concerns about the impact of groundwater use on local stations, tourism operators, and the Bidyadanga community, with the key issues listed as:

- the potential negative impact on local area bores (stock and drinking water) through increased salinity or drawdown effects;

- the potential for pesticides and fertilisers to leach into the groundwater and affect local stock and drinking water resources; and

- the availability and suitability of groundwater for other existing or future agricultural activities in the area such as horticulture. (Beckwith and Associates, 1999: 7)

Some stakeholders were concerned that the Water and Rivers Commission would allocate all the groundwater, up to what was to be determined a sustainable limit, to the single development proponent WAI. The other issues that Beckwith and Associates identified were: the unclear relationship between native title and the allocation of water; and, the need to assess and protect local Aboriginal cultural values, particularly in relation to water, as well as traditional food sources more generally.

Because of the lack of knowledge about the groundwater and local ecologies, together with the scale of the proposal, many people emphasised the need to be cautious and careful in water planning through the application of the precautionary principle. The precautionary principle was devised by policy makers and ecologists to argue that 'where there are threats of serious or irreversible environmental damage, lack of full scientific certainty should not be used as a reason for postponing measures to prevent environmental degradation' (Ecologically Sustainable Development Steering Committee, 2002). Some stakeholders argued that the precautionary principle was important to apply up front, because it would be difficult both politically and administratively for the Water and Rivers Commission to stop or wind back an established cotton industry, if negative impacts were occurring. 
As the main issues raised by the stakeholders included both environmental and cultural values, the Water and Rivers Commission contracted anthropologist Sarah Yu to lead a team working on Aboriginal cultural values, as well as a parallel study by wetland scientists Vic and Christine Semeniuk on hydroecological values (Yu, 1999; Semeniuk and Semeniuk, 2000).

The report prepared by Sarah Yu is based on interviews with Karajarri, Mangala, Nyikina, Yawuru, and Nyangumarta traditional owners, with a focus on Karajarri because most of their traditional country was within the study area, although, the significance of water stories is shared between all these groups. In the report, $\mathrm{Yu}$ details how water is described by the traditional owners in terms of life, and permanent water sources are known in Aboriginal English as living waters. Knowing where and how to get water is essential for survival in the Great Sandy Desert. Living waters may be surface waters, which may or may not require digging, and all are connected to the underlying water table. This underground water is called kurtany, which means 'mother of underground water' (Yu, 1999: 21). The living waters are all known as manifestations of pukarrikarri - the world-creation epoch of supernatural beings, also loosely described as the Dreaming. The living waters are evidence of the continuation of the pukarrikarri, and associated narratives, and are fundamental to understanding country, both geographically and temporally. Water sources can also be sites where Karajarri 'arose', as each Karajarri individual is intimately connected to sites in their country where they were created (Yu, 1999: 23). The living waters also relate to kinship and marriage arrangements (Yu, 1999: 33). Nyikina Elder Harry Watson has described these many relationships:

There are inside stories for living waters, known all over the country. They've all got connections. The Law is big. It is not passive, it's active. We can't speak about this. It's not public. Water, culture and land. That's our ngurrara [country]. You can't divide them, doesn't matter which language you speak. (H Watson, interview at the Groundwater Committee meeting, Broome, 29 October 1999, in, Yu, 1999: 30)

Yu documents how Karajarri people also believe in pulany, water snakes or serpents, who reside in and, or, made the permanent water sources. These permanent water sources are called jila or pajalpi. Where there are panyjin reeds at the water sources, this often indicates the presence of pulany. Pulany have distinctive personalities, some are dangerous, others are docile, and active pulany travel underground, surfacing through escape holes called tulkarru. Most pulany interact with one another. Evidence of their activity is revealed in the formation of clouds, and storms with lightning and rain. When angry, the storms are violent, and the pulany can kill by drowning, battering or eating people (Yu, 1999: 18-20). Because the pulany are unpredictable, Karajarri do not camp in the immediate vicinity of living waters. 
The changing seasons are 'put down by pukarrikarri' and the seasonal replenishment of rain is promoted by the pulany who make the living waters such as jila. Karajarri understand the health of the living waters as an indicator of the health of country. They must never dry up. When the living waters fill up, the other water sources in country will be replenished. Thus, kurtany, the mother of the ground water, through the generation of rain by the jila, makes everything strong and healthy. With the replenished springs, the trees, animals, plants and people live off this water until the next rains. Even saltwater fish, such as mullet and bream, drink the fresh rainwater during the wet by coming to the surface of the ocean with their mouths open (Yu, 1999: 29-30). In this way the living waters are not just the permanent springs, but generate life for the whole of country, people included.

It is clear from these interviews that Karajarri must respect the seasonal cycle of water use and replenishment for their own survival, and this is also their responsibility as traditional owners. This respect will ensure that the water table or water level is maintained in the permanent sources of water. There are correct protocols, and knowledge passed down through song and narrative to ensure future generations will be able to continue these responsibilities. There are rainmaking ceremonies to persuade the pulany to 'get up' and make rain. Also, pulany can identify strangers and Karajarri were careful on fieldwork to ensure such people were appropriately introduced to the water sources. A Karajarri Elder, since passed on, spoke about the importance of this work:

We have to look after this water. If the water go, everything will be finished. Life gone. Spirit gone. People gone. The country will have no meaning. (JDN, interview, Bidyadanga, 8 October 1999, in, Yu, 1999: 32)

Wetland scientists Vic and Christine Semeniuk had as their objective the identification of wetland types, especially those wetlands of significance, and the determination of the hydrological mechanisms maintaining them. The wetlands were assessed as to their 'value' and 'function': value was described as the importance, merit, or worth of a wetland after evaluation; and function being the role a wetland performs in its natural setting (such as water and food source, habitat, drought refuge, breeding ground, collection point for a range of ephemeral drainage lines, and hydrological discharge zone). Semeniuk and Semeniuk categorised and described different wetland types, and the assemblage of plants that occurred in each habitat. They found that the wetlands are maintained in four ways: surface water flows from drainage lines; water table rise; the ponding of water by the near surface hardpans; and, by upward leakage from formational waters (formational waters are waters that were either originally rainwater or sea water, but have since undergone substantial transformation). Their report divided the hydrology of the Great Sandy Desert into three zones: the northern section where mainly fresh groundwater 
resides at depth in the Broome Sandstone, with the water table in excess of ten metres below the surface; a southern section where fresh, brackish to saline groundwater is shallow, located beneath a calcrete and limestone sheet; and a coastal section, where fresh to saline groundwater is found in coastal aquifers. They described the Broome Sandstone as not internally homogenous in terms of rock types and cementation, with the transmission of water being a complex relationship in different sedimentary environments; sand dominated, to fluvial (sand and mud), and coastal tidal flat (sand with more mud sheets).

Along the coast, the variety of wetlands are categorised according to whether the wetlands are a combination of fresh and salt water (such as the mangrove systems), or where impeded freshwater has formed small to large clusters of lake-like wetlands. There are also springs along the upper shore zone and low tidal zone where freshwater has found pathways through the Broome Sandstone. With inland wetlands, Semeniuk and Semeniuk categorised a range of types: those that have developed along drainage lines with large fluvial discharge, these wetlands are described as 'windows to the regional water table'; those that are also located along drainage lines, but have overflow whereby water ponds to form clay-lined pans; clay or muddy sand floored wetlands that are along relict drainage lines; pans that have developed along low relief drainage lines; and peat mounds, which are wetlands formed around springs. Particular areas challenge these neat categories, such as the Salt Creek Line which has a range of sediment types and wetlands.

Semeniuk and Semeniuk concluded that the wetlands are varied and complex in origin and maintenance, with significant values in terms of biota and geoheritage. Further, that the Broome Sandstone cannot be categorised as a simple unconfined aquifer. Because of the complex pathways and springs of inland and coastal wetlands, Semeniuk and Semeniuk recommended that the dynamics of the groundwater be further investigated to better understand how these wetlands are maintained. They advised against assuming that abstracting water from the Broome Sandstone would not affect the wetlands in the region. This advice contradicted the argument that the fresh groundwater was being wasted out to sea. The groundwater was shown to support culturally and ecologically significant wetlands along the coast and inland.

Together, the three reports by Beckwith and Associates (1999), Yu (1999) and Semeniuk and Semeniuk (2000) revealed what an enormous impact a single large development proposal could have on the local community, local futures, traditional owner identity and relationships with country, and the health of complex freshwater ecosystems in a very arid environment. Karajarri most directly expressed how water is a life-giving source, and a key relationship that they must respect to ensure the health of country. However, this relationship was also central to the two reports on stakeholders and hydro-ecological 
values, which revealed the many activities and connections that have thrived on a healthy water source. Rather than treating water as just another resource input for the irrigation industry, the reports illustrated how the extraction and consumption of large amounts of water could widely compromise local reliance on La Grange groundwater as a life source.

\section{The process of engagement}

The engagement between Karajarri and the Water and Rivers Commission is one of Australia's first examples of a substantial consultation process with Indigenous people over a specific water allocation (Jackson, 2009: 43). There were three key parts to this consultation:

- the methodology for the cultural and ecological studies;

- the focus on process issues around stakeholder involvement; and

- the recognition of the distinct role of traditional owners, especially Karajarri;

A significant innovation in the engagement was that the Water and Rivers Commission instructed the wetland scientists Semeniuk and Semeniuk and the anthropological team led by Sarah Yu to undertake their fieldwork together. Through this experience, the traditional owners and the scientists enjoyed exchanges in their expertise. The wetland scientists gained local knowledge of the location of wetlands, as well as their water permanence throughout the seasons and over the many years of Karajarri observation and knowledge. This helped Semeniuk and Semeniuk to work more effectively within their limited budget and time. Karajarri were able to ensure the scientists' work was conducted according to cultural protocols. Karajarri and other traditional owners were also very interested in the scientific understanding of groundwater hydrology and how the wetlands were supported. Mervyn Mulardy Jnr talked about the exchange:

Bidyadanga water is very old, maybe over a million years old. We went to a place called Juwurr-kara and Juwurr-kakara jilla springs. A lot of places had Baler shells, which the old people used to carry water. The scientist checked this waterhole and got a shock. In the whole of Australia, the purest water is the monsoon rains in north Queensland. But he was fascinated that he found it at the same level as that waterhole. He couldn't get over it. (Mervyn Mulardy Jnr, interview, Bidyadanga, 14 October 2008)

The two teams also found they had much commonality in their knowledge, as Mulardy Jnr said: 
The old people had names for different levels of ground water, and how it moves. At the end of the day, everything the old people were saying matched up with the scientific version. So the scientific knowledge and traditional knowledge were the same. (Mervyn Mulardy Jnr, interview, Bidyadanga, 14 October 2008)

Both the traditional owners and the wetland scientists agreed on many points, and this was reported in both reports. There was agreement on the direction of groundwater flows at particular sites, the layers of groundwater, and that the coastal springs are fed by underground water that comes from the high country inland (Yu, 1999: 34). There was also agreement across the categorisation of different types of wetlands (see Tables 5.2 and 5.3). However, even though there is a clear link between cultural values and water places, cultural knowledge and ecological knowledge cannot be equated (see Weir, this volume). There remains a strong imperative for the role of Indigenous people and their knowledge in water decision making, which cannot be replaced by scientific expertise.

\section{Table 5.2: Terminology employed by local Aboriginal people for the wetlands}

$\begin{array}{ll}\text { Water type } & \text { Description } \\ \text { lirri } & \text { Soaks, in which water is dug up for drinking. Some are } \\ & \text { permanent (lakes), others are dug up in the hot time } \\ & \text { (sumplands and damplands). } \\ & \text { Permanent water sources. In some cases jila have visible } \\ \text { jila } & \text { surface water (lakes and peat mounds), but many require } \\ & \text { digging. A jila may be marked by a small depression in the } \\ & \text { ground. Scrubby t-trees may surround the water. Jila occur } \\ & \text { in clayey soil from which the white mud kalji is found. } \\ \text { pajalpi } & \begin{array}{l}\text { Ecosystems surround springs, as permanent water sources } \\ \text { found on fringes of coastal mudflats, or inland areas. } \\ \text { wawajangka }\end{array} \\ & \text { Fresh water seepages found in mudflats in the intertidal zone } \\ & \text { and only accessible at low tides. } \\ \text { pirapi } & \text { Claypans (sumplands) that fill with water after rain, and } \\ & \text { usually dry up after the rain or as the hot time approaches. }\end{array}$

Source: Semeniuk and Semeniuk (1999): 12. The terms in brackets signify the classification that was used by the scientists. 
5. Water Planning and Native Title: A Karajarri and Government Engagement in the West Kimberley

Table 5.3: Practical classification, technical classification, and Aboriginal terminology

$\begin{array}{lll}\text { Practical classification } & \text { Technical classification } & \text { Aboriginal terminology } \\ \text { oasis } & \text { lakes, sumplands, playas } & \text { jila, some pajalpi } \\ \text { pan } & \begin{array}{l}\text { sumplands, damplands, } \\ \text { playas }\end{array} & \text { lirri, pirapi } \\ \text { spring } & \text { peat mounds } & \text { pajalpi }\end{array}$

Source: Semeniuk and Semeniuk (1999): 13.

The interactive fieldwork methodology also provided additional opportunities for dialogue about the many close connecting relationships with ecological and cultural values. The close relationships held are reflected in the maps the teams produced, which showed a strong correlation between the ecological and cultural sites. Key areas included the wetlands that form a parallel line just inland from the coast, and the Mandora Marshes and Salt Creek System that include one of the furthest inland saltwater mangroves in Australia. Overall, the maps of the study area reveal that the cultural sites are more widespread than those sites of high ecological value. This mapping work enabled the Water and Rivers Commission to undertake their own preliminary mapping to guide as to where possible irrigation development might or might not occur. This mapping work is reflected in the management zones in the most recent La Grange management plan (Figure 5.1). However, even though there is a clear link between cultural values and water places, cultural knowledge and ecological knowledge cannot be equated (see Weir, this volume). The role of Indigenous people and their knowledge in water decision making cannot be replaced by scientific expertise.

A key objective of the report on stakeholder issues was to identify stakeholders and a process for further community involvement (Beckwith and Associates, 1999: 3). This reflected the priority of the Water and Rivers Commission, who wished to identify the key people for ongoing dialogue about the West Kimberley Irrigation Proposal, its development and sustainability, as well as how these people would be involved in the water planning process.

Out of the scoping work undertaken by Beckwith and Associates, all the key stakeholders agreed upon how the Water and Rivers Commission would consult in developing the allocation plan (Figure 5.3). The La Grange Groundwater Committee was formed in 1999 with representation from 18 key locally based stakeholders (government and non-government) with a significant interest in water issues. The Committee, which had an independent chairperson, provided comment and advice to the Water and Rivers Commission on water allocation issues associated with the La Grange groundwater area but did not have any formal decision making powers. Separate dialogues were held for local users, 
other stakeholders and the general public. Karajarri and the Bidyadanga Community Council had representation on the Groundwater Committee to present their issues and perspectives.

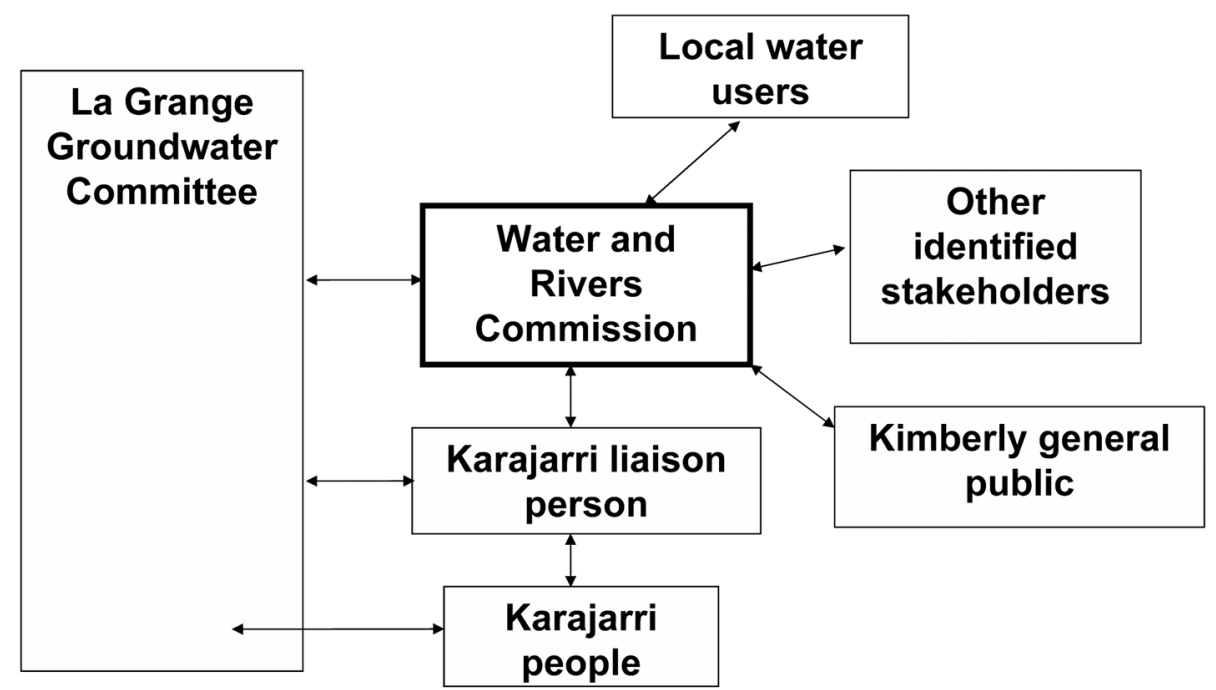

Figure 5.3: Public involvement model for the La Grange groundwater allocation planning process.

The Water and Rivers Commission also appreciated the importance of direct dialogue with Karajarri as the main traditional owners for the planning area they had identified for the La Grange groundwater. Protocols were established to ensure this relationship was respected. In Bidyadanga, the Water and Rivers Commission would meet first with the Karajarri, before meeting with the Bidyadanga Community Council. This enabled direct discussion of the upcoming meeting agenda, the exchange of concerns, and to update the Commission of any Karajarri news. By doing so, the Commission were able to communicate with Karajarri as a group, rather than just the Karajarri representatives on the Groundwater Committee. Further, Mervyn Mulardy Jnr was employed as the Aboriginal Resource Person for La Grange groundwater planning, a liaison position to provide the interface and translation between the Commission and Karajarri.

After the failure of the cotton proposal, the new authority, replacing the Water and Rivers Commission, the WA Department of Water re-commenced the planning process for La Grange water. The 'Draft La Grange groundwater sub area water management plan - allocation' was released in late 2008 for public comment. As part of this planning process, innovative engagement with the traditional owners has continued. The Department of Water funded a film in plain English and Karajarri to describe the new consultation process and water allocation plan (Mathews, 2008). The film begins with the camera zooming into the panyjin 
reeds at a jila, which are often the indicators of pulany being present. Mervyn Mulardy Jnr speaks throughout the film about how the planning process is to share the water 'right way', with people from other communities, farms, cattle stations, and outstations, and to look after the water to keep it healthy and alive. He explains that the government will take some La Grange groundwater every year, and that Karajarri will need to make sure there is enough water for their culture and future development. Mulardy Jnr describes the water licences, the paperwork, and how licences do not give ownership to the water, and the ongoing government process of monitoring those licences. The film was made to encourage people to engage with the process because, as Mulardy Jnr says in the film, 'It's our right to look after all ngapa (water) places, and we've got to make the right decision.'

The active engagement approach by the Department of Water with Karajarri was also evident in a recent licence application from the pastoralist managing Nita Downs station, who wished to diversify into horticulture. The Department arranged for a consultation meeting on Nita Downs between Karajarri and the station leaseholders about the proposal, to ensure cultural and other Indigenous interests were allowed for as part of the licence application assessment process, as well as to better inform Karajarri about water licences and regulation. During the trip, Karajarri took the opportunity to harvest bush tucker. Karajarri man Joe Edgar has spoken about how the pastoralist was astounded by this food collection, which he did not realise was so readily available (Edgar, 2009).

Such levels of engagement are respectful of the issues being raised by the local community, and the unique relationships traditional owners hold with country. It has set a standard for future engagement with Indigenous people in water planning in Western Australia and Australia. Although the Water and Rivers Commission have been criticised for not engaging more broadly with traditional owners, including Yawuru people to the North and Nyangumarta people to the south, as the La Grange groundwater involves a much bigger area than Karajarri country.

The National Water Initiative requires Indigenous people to be involved in water planning, and their issues to be considered in water management, however in WA there is no such state legislation enforcing this. There was no legislative or policy need for the Department of Water to facilitate good engagement processes with Karajarri, such as the Nita Downs trip. Despite all this good work, these processes are not securely imbedded in law and policy. Generally, in WA there is a lack of Indigenous peoples' involvement in water resource monitoring and management, a lack of policy on Indigenous peoples' access to water and economic use, and a lack of adequate equitable water service provision for many Indigenous communities. 


\section{Water decision making}

The original planning around La Grange water allocations took place in a context that was dominated by a single large scale cotton irrigation proposal. In 2010 the Department of Water finalised the La Grange water allocation plan. The plan has rules for water use and the monitoring of that use which give consideration to ecological, social and cultural values. The plan sets the allocation of water for consumptive purposes at about a quarter of the initial estimate of water potentially available when the WAI cotton irrigation proposal commenced. A total allocation limit of 50 gigalitres per year is established for all consumptive uses in the La Grange Basin (Department of Water, 2010: 37). Water is still allocated on a first come, first allocated basis, which will advantage those development proponents who have a proposal ready to apply. The Department of Water acknowledges that the traditional owners require certainty that a commercial water allocation will be available if and when they seek it, and is considering how to address this (Department of Water, 2010: 19). Karajarri still worry if the water plan will be 'right way' for country (Mulardy Jnr cited in Mathews, 2008). There is always the opportunity for an agreement between the government and traditional owners to facilitate their greater involvement in water planning and allocation, although this is constrained by narrow interpretations of native title.

The problem with planning is that it is hard to evaluate activities before they are undertaken. This is why the precautionary principle approach is so important. The La Grange allocation plan acknowledges the complexity of the salt and fresh water interface and the importance of increased management and monitoring before any significant increase in water use occurs. As Mervyn Jnr said in the film, the Plan has 'harder rules' for the significant ecological and cultural areas along the coast, and the Mandora Marshes and Salt Creek System. Applicants for new water extractions are required to demonstrate that their proposed development will be sustainable in the long term. The Department may require additional work to be done by the applicant to make sure that groundwater extraction has negligible impact on the social, cultural or ecological values of wetlands or other groundwater dependant ecosystems.

The Karajarri's native title determination over most of the area of the La Grange Basin makes them a major player in any proposed large scale groundwater development. In determination area A, which covers Frazier Downs and a substantial area of Crown radical title, Karajarri people have exclusive native title rights. This includes 'the right to control access to, and activities conducted by others on the land'. As with the WAI proposal the Department of Water would require any applicant for a large scale development to carry out regional level groundwater investigation work on the inland Crown radical title to be able to 
determine groundwater availability. The applicant would need to negotiate an access agreement with the Karajarri to do this work. The Karajarri also have exclusive native title rights to the Frazier Downs pastoral lease area and could develop a sustainable irrigated agriculture business on this land.

Overall, three key studies were undertaken as part of the initial phase of the planning process: an overview of stakeholder issues by consulting company Beckwith and Associates (1999); a report on Aboriginal cultural values by anthropologist Sarah Yu (1999); and, a hydro-ecological survey of the wetlands of the north-western Great Sandy Desert by wetland scientists Vic and Christine Semeniuk (2000).

\section{Concluding remarks}

Water issues bring people together through the far reaching connections that water sustains. The life sustaining properties of water were acknowledged in the three reports by Semeniuk and Semeniuk (2000), Beckwith and Associates (1999) and Yu (1999), albeit in different languages with different priorities, values and methodologies emphasised. The water management and planning work of the Department of Water uses another language again, but also emphasises protecting groundwater dependant cultural and ecological values and managing sustainable use. Where people share commitment to sustaining fresh water ecosystems, their different knowledge traditions, skills and approaches generate a dynamic dialogue for water planners and decision makers to draw on.

The WAI large scale cotton proposal focused on treating water as a commercial resource and was not sensitive to considering the other roles of water, including being a fundamental life source. The proposal ultimately failed. Whilst this opportunity for development was forgone, Karajarri and many others are able to continue to enjoy all the life of the desert country that is sustained by La Grange groundwater. They also have the opportunity to plan for and invest in development proposals that may have stronger links with and outcomes for the local community. Critically, the failure of the WAI proposal has enabled a much longer time frame for water planning, research and engagement with key parties.

What is unique about the La Grange planning work is how the joint cultural and ecological fieldwork revealed the common ground held between Indigenous and hydro-ecological knowledge, thereby facilitating the immediate relevance of Karajarri water knowledge to water management and planning processes. Karajarri water knowledge is multi-layered, complex and restricted, and central to their native title. This is productive knowledge that can be engaged with in water management and the development of sustainable water consumption industries. Good process is central to ensuring this engagement is meaningful. 
Negotiations over water will intensify as proposals to develop agriculture in northern Australia gain traction. Aboriginal people are central to these negotiations, as evident in the recognition of their native title rights and their extensive knowledge about country. Whilst, as yet, Karajarri do not have recognised rights to a water allocation, they clearly wish to be involved in water management and planning. The time and energy invested into this water management planning for the La Grange groundwater, has hopefully provided for a water management plan which all parties can identify with. In any case, Karajarri will continue to work to ensure water will be there for country, for future generations of native title holders, and for everybody else, because the living waters are central to Karajarri people, law, country and their way of life.

\section{References}

Beckwith and Associates 1999, 'La Grange Groundwater Allocation, A Kimberley Sub-Regional Allocation Plan, Overview of Stakeholder Issues', report prepared for the Water and Rivers Commission, Perth.

Department of Water 2010, 'La Grange Groundwater Allocation Plan, Water Resource Allocation and Planning Series', Report no 25, Department of Water, Perth.

Department of Water 2008, 'Draft La Grange Groundwater Sub Area Water Management Plan - Allocation', Department of Water, Perth.

Ecologically Sustainable Development Steering Committee 2002, National Strategy for Ecologically Sustainable Development, part 1, Department of Environment, Canberra.

Edgar, J forthcoming, 'Indigenous Land Use Agreement - Building relationships between Karajarri traditional owners, the Bidyadanga Aboriginal Community, La Grange Inc and the Government of Western Australia', Australian Aboriginal Studies.

Edgar, J 2009, presentation to the National Indigenous Water Planning Forum on 19 February 2009, Adelaide, National Water Commission.

Jackson, S 2009, National Indigenous Water Planning Forum: Background Paper on Indigenous Participation in Water Planning and Access to Water, CSIRO, Darwin.

Mathews, D 2008, Ngapa, translation DVD for the La Grange Water plan, English, Kriol and Karajarri language, Department of Water. 
5. Water Planning and Native Title: A Karajarri and Government Engagement in the West Kimberley

National Native Title Tribunal 2009, Determination of Native Title: Karrajarri People A (2002) Karajarri People B (2004), Geospatial services, National Native Title Tribunal.

- 2011, Kimberley Native Title Applications and Determinations Areas, Geospatial services, National Native Title Tribunal.

Ross, J 2009, 'Sustainable Development in Northern Australia', A report to Government from the Northern Australia Land and Water Taskforce, Department of Infrastructure, Transport, Regional Development and Local Government.

Semeniuk V and C Semeniuk 2000, 'Wetlands of the Northwestern Great Sandy Desert in the La Grange Hydrological Sub-basin', report prepared for the Water and Rivers Commission, Perth.

Strelein, L and J Weir 2008, 'Our Public and Private Relationships with Water and Native Title', seminar presentation, Australian Institute of Aboriginal and Torres Strait Islander Studies Seminar Series, 25 August 2008.

Weir, JK 2011, Karajarri: A West Kimberley Experience in Managing Native Title, Discussion Paper Number 30, Native Title Research Unit, Australian Institute of Aboriginal and Torres Strait Islander Studies, Canberra.

Yu, S 1998, 'Land Interests of Karajarri in the Area around Port Smith Caravan Park', report to support application to the Indigenous Land Corporation to purchase special lease 3116/9994: Port Smith Caravan Park.

- 1999, 'Ngapa Kunangkul: Living Water', report on the Indigenous cultural values of groundwater in the La Grange sub-basin, prepared for the Water and Rivers Commission, University of Western Australia, Perth.

\section{Cases}

Mabo v Queensland [No 2] (1992) 175 CLR 1

Nangkiriny $v$ Western Australia [2002] FCA 660 (12 February 2002)

Nangkiriny $v$ Western Australia [2004] FCA 1156 (8 September 2004)

Western Australia v Ward [2002] 213 CLR 1 (8 August 2002)

Yanner v Eaton [1999] 201 CLR 351 (7 October 1999)

\section{Legislation}

Native Title Act 1993 (Cth) 